\title{
SPINAL ANAESTHESIA-INDUCED HYPOTENSION IN OBSTETRICS: PREVENTION AND THERAPY
}

\author{
Ivan Šklebar ${ }^{1,2,3,4}$, Tonka Bujas ${ }^{5}$ and Dubravko Habek ${ }^{2,6}$
}

\begin{abstract}
${ }^{1}$ Clinic for Anaesthesiology, Reanimatology and Intensive Care, "Sveti Duh" University Hospital Zagreb, Zagreb, Croatia; ${ }^{2}$ Catholic University of Croatia; ${ }^{3}$ Osijek Faculty of Medicine, Osijek, Croatia; ${ }^{4}$ Bjelovar University of Applied Sciences, Bjelovar, Croatia; ${ }^{5}$ Dr. Josip Benčević General Hospital, Department of Anaesthesiology, Reanimatology and Intensive Care, Slavonski Brod, Croatia; ${ }^{6}$ Sveti Duh University Hospital, Clinic for Gynaecology and Obstetrics, Zagreb, Croatia
\end{abstract}

SUMMARY - Regional centro-axial anaesthesia, primarily spinal block, is the preferred method of anaesthesia for elective caesarean section because it entails fewer risks for the mother and the foetus compared to general anaesthesia. The most common side effect associated with spinal block is hypotension due to sympatholysis, occurring in up to $75 \%$ of cases. Spinal block-induced sympatholysis leads to vasodilatation and consequently causes maternal hypotension, which may compromise uterine blood flow and foetal circulation, and thus cause foetal hypoxia, bradycardia and acidosis. The selection of the most efficient treatment strategy to achieve haemodynamic stability during spinal anaesthesia for caesarean section continues to be one of the main challenges in obstetric anaesthesiology. A number of measures for the prevention and treatment of spinal block-induced hypotension are used in clinical practice, such as preloading and coloading with crystalloid and/or colloid infusion, wrapping of lower limbs with compression stockings or bandages, administering an optimal dose of local anaesthetic and achieving an optimal spinal block level, left tilt positioning, and administering inotropes and vasopressors. Instead of administering vasopressors after a drop in blood pressure has already occurred, the latest algorithms recommend a prophylactic administration of vasopressor infusion. The preferred vasoconstrictor in this case is phenylephrine, which is associated with a lower incidence of foetal acidosis, and maternal nausea and vomiting compared to other vasoconstrictors.

Key words: spinal anaesthesia, caesarean section, hypotension, crystalloids, colloids, vasopressors, ephedrine, phenylephrine, norepinephrine, ondansetron

\section{Introduction}

Spinal anaesthesia is the method of choice for caesarean section, especially in case of elective procedures, because it avoids the most common risks associated with general anaesthesia, such as aspiration, difficult intubation and negative effects of general anaesthetics on the foetus (1). However, certain side effects may also result from spinal anaesthesia, the most common being hypotension caused by the preganglionic sympathetic

Corespondence to: Assist. Prof. Ivan Šklebar, $M D$, PhD, Sveti Duh University Hospital, Clinic for Anaesthesiology, Reanimatology and Intensive Care, Sveti Duh 64, 10000 Zagreb, Croatia

Email: isklebar@gmail.com block. Spinal block-induced sympatholysis leads to vasodilatation and consequently causes hypotension in mothers. A decrease in systolic pressure can compromise uterine blood flow and foetal circulation, and thus cause foetal hypoxia and acidosis $(1,2)$. Hypotension during caesarean section performed under spinal anaesthesia has been the subject of medical research for more than 50 years (3). The incidence of hypotension during spinal anaesthesia for caesarean section varies in different studies, ranging from $7.4 \%$ to $74.1 \%(1,4)$. The selection of the most efficient treatment strategy to achieve haemodynamic stability during spinal anaesthesia for caesarean section continues to be one of the main challenges in obstetric anaesthesiology. 


\section{Definition of spinal anaesthesia-induced hypotension}

In order to determine the incidence of spinal anaesthesia-induced hypotension in obstetrics and establish the best course of treatment, it is crucial to precisely define hypotension because different studies use different definitions of the term.

$\mathrm{Klöhr}$ et al. performed a systematic literature review and found 15 different definitions of hypotension in 63 studies on hypotension following spinal or combined spinal-epidural anaesthesia for caesarean section in the period from 1999 to 2009 (4). All these studies used systolic arterial pressure (SAP) measured in the arm in different body positions. Some studies distinguish between severe and less severe hypotension. The two most common definitions of hypotension used in research studies are either decrease to $80 \%$ of the baseline blood pressure value measured before anaesthesia or a combination of two criteria, i.e. a drop of SAP to $100 \mathrm{mmHg}$ or lower, or a drop to 80\% baseline or lower (4). A 1999 study conducted in the UK found that most consultant obstetric anaesthetists use a hypotension threshold of either 100 or $90 \mathrm{mmHg}$ of SAP (5). Application of different definitions of hypotension used in literature to a cohort of women undergoing elective caesarean section renders an incidence of hypotension that varies between $7.4 \%$ and $74.1 \%(1,4,5)$.

Ngan Kee et al. have shown a significant improvement in the reduction of incidence of nausea and vomiting when SAP was maintained at the baseline level, compared with $90 \%$ to $80 \%$ of baseline SAP levels (6). Therefore, the consensus published in 2018 suggests that the aim should be to maintain SAP $\geq 90 \%$ of the baseline measured before spinal anaesthesia and to avoid a drop to $80 \%$ of the baseline value (7).

\section{Pathophysiology and consequences of hypotension during spinal anaesthesia}

Spinal anaesthesia causes hypotension via several pathophysiological mechanisms, the most significant being rapid onset of sympatholysis due to increased sensitivity of nerve fibres to local anaesthetics during pregnancy $(8,9)$. The level of blockage of the sympathetic chain is connected to the degree of cranial spread of the local anaesthetic within the subarachnoid space, it is often difficult to predict and usually reaches several dermatomes above than the sensory block level (10). Higher sensitivity to local anaesthetics combined with aortocaval compression of the pregnant uterus are the main reasons for increased incidence and higher levels of hypotension in pregnant women, compared to non-obstetric patients (8-11). Pregnant women also exhibit an increased level of sympathetic activity compared to parasympathetic activity $(9,12)$. Sympatholysis therefore leads to a higher degree of peripheral vasodilatation and a predominance of parasympathetic activity, consequently reducing the venous return and cardiac pre-load, and resulting in bradycardia, nausea and vomiting. The reduced pre-load in turn results in reduced cardiac output (CO), leading to systemic hypotension. This state is further aggravated by aortocaval compression $(11,12)$. Higher sympathetic block proportionally reduces the occurrence of compensatory mechanisms via baroreceptors and increases the risk of cardioinhibitory reflexes such as the Bezold-Jarisch reflex and, ultimately, cardiac arrest and death $(11,13)$.

Nausea and vomiting occur significantly more frequently during spinal anaesthesia for caesarean section compared to non-obstetric surgery, and are primarily caused by hypotension. Acute hypotension reduces cerebral perfusion, induces transient brainstem ischemia and activates vomiting centres (14). This may also result in transient cerebral hypoxia connected with a significant decrease in maternal cerebral blood volume, cerebral oxygen saturation and oxygenation, as shown in studies conducted with near-infrared spectroscopy (NIRS) (15). This is also in line with the observation that oxygen inhalation may prevent cerebral hypoxia and reduce the incidence of nausea $(16,17)$. Severe and prolonged maternal hypotension may result in vertigo and decreased level of consciousness, which occurs less often when the drop in blood pressure is immediately treated.

Spinal anaesthesia reduces splanchnic blood flow by approximately $20 \%$, which is additionally pronounced in case of systemic hypotension (18). Splanchnic hypoperfusion results in the release of emetogenic substances, such as serotonin, from the digestive tract which is another pathophysiological mechanism of nausea and vomiting (14).

Studies on the effect of hypotension occurring during caesarean section on foetal physiology in humans remain scarce; however, research conducted on animals 
shows that continued reduction in uteroplacental blood flow $>60 \%$ results in bradycardia and acidaemia in a previously non-compromised foetus (19). Neonates born to mothers with spinal anaesthesia-induced hypotension were significantly more acidotic (20). Hypotension lasting longer than 2 minutes was connected with a significant increase in oxypurines and lipid peroxides in the umbilical vein, which is indicative of an ischaemia-reperfusion injury (21). The duration of hypotension plays a more important role than its severity. A transient pressure drop $\geq 30 \%$ did not affect the Apgar status of the neonate, incidence of the meconiumstained amniotic fluid or the need for oxygen therapy of the neonate (22). Hypotension in the duration shorter than 2 minutes did not affect the neurobehavioral outcome, whereas maternal hypotension lasting longer than 4 minutes can be linked with neurobehavioral changes in the first 4 to 7 days of the neonate's life $(20,23)$. The choice of vasopressor used for the treatment of hypotension is an important element for the interpretation of the neonate's acid-base status. Clinical studies have shown that phenylephrine is associated with a more favourable acid-base status of the neonate, compared to ephedrine $(24,25)$.

\section{Prevention and treatment of spinal anaesthesia-induced hypotension}

Due to potentially severe consequences for both mother and foetus, prevention and treatment of spinal anaesthesia-induced hypotension during caesarean section have been subject of numerous scientific and clinical studies ever since this type of anaesthesia was first applied. Many studies examine the effect of crystalloid and colloid preloading and/or coloading on the prevention of hypotension $(26,27)$. As the prevention of hypotension by administration of a 500 to $1500 \mathrm{~mL}$ crystalloid preload did not prove to be effective due to quick redistribution of crystalloids in the organism, the new approach was coloading, i.e. rapid administration of crystalloids simultaneously with an induction of spinal anaesthesia, which somewhat improved the effect of this method (28). Administration of colloids instead of crystalloids or their combination can additionally reduce the incidence or severity of hypotension, but also involves an increased risk of colloid anaphylaxis (29). In order to reduce the negative haemodynamic effects of spinal anaesthesia for caesarean section, it was shown that adequate anaesthesia could be achieved by reducing the local anaesthetic dose to 5-7 mg of bupivacaine (30). As low doses increase the risk of insufficient anaesthesia duration or incomplete block, this method is recommended in case of combined spinal-epidural anaesthesia (30). In order to prevent the reduction of preload, research was also conducted into the effects of wrapping the lower limbs with compression stockings or bandages, which also showed some effect on the prevention of hypotension, as well as using the Trendelenburg position up to 20 degrees $(31,32)$.

Considering that the aforementioned methods for the prevention of hypotension do not provide a satisfactory level of efficiency, administration of vasoactive medication was proven to be essential. Dopamine was one of the first used, followed by ephedrine, and recently phenylephrine and norepinephrine $(7,8,33)$. Ephedrine was initially administered as bolus after a drop in blood pressure during spinal anaesthesia, whereas a later suggestion was to administer it as continuous infusion $(25,33,34)$. Despite similar effects of ephedrine and phenylephrine on the prevention and treatment of hypotension in pregnant women during spinal anaesthesia, administration of phenylephrine was associated with a lower incidence of foetal acidosis and maternal nausea and vomiting, making it the preferred vasoconstrictor in obstetric anaesthesia $(34,35)$. In order to achieve optimal management of blood pressure during spinal anaesthesia for caesarean section, it is recommended to combine coloading with 1000 to $2000 \mathrm{~mL}$ of crystalloids and a continuous infusion of phenylephrine at $25-50 \mathrm{mcg} / \mathrm{min}$ immediately after intrathecal anaesthetic injection $(7,36)$. Phenylephrine should be titrated depending on blood pressure (measured every 2 minutes) and pulse with additional boluses as required. The goal is to maintain the systolic arterial pressure $\geq 90 \%$ of baseline measured before spinal anaesthesia and to avoid a drop to $<80 \%$ of baseline value $(1,7,36)$. Since phenylephrine use can cause severe bradycardia, norepinephrine has been studied recently as a possible alternative to phenylephrine (37). The use of norepinephrine is still in the experimental stage, but the results so far suggest that it could be a good alternative to currently used vasopressors, especially when we want to avoid bradycardia $(37,38)$.

In the last 10 years, more than 150 studies were published describing the effect of ondansetron on the 
prevention of hypotension during spinal anaesthesia, as well as bradycardia. The mechanism of ondansetron's activity is attributed to blockage of serotonin receptors (5-HT3), resulting in the interruption of the cardioinhibitory Bezold-Jarisch reflex from chemoreceptors. The reflex appears as a paradoxical reaction to a sudden drop of blood pressure, causing further degradation of compensatory mechanisms of the circulatory system $(13,39)$. A meta-analysis of 13 randomised controlled trials by Tubog et al. has shown that the incidence of hypotension is reduced by an average of $36 \%$ (from $12 \%$ to $73 \%$ ), whereas the incidence of bradycardia is reduced by $69 \%$. Ondansetron was administered intravenously 5 minutes before the start of the spinal block, with doses varying from 2 to $26 \mathrm{mg}$ (40). Even though these results support the hypothesis on the positive effects of ondansetron in the prevention of spinal block-induced hypotension, due to the heterogeneity in terms of samples, local anaesthetics mixtures, results and applied doses of ondansetron, it is still early to recommend its routine administration in obstetric spinal anaesthesia for caesarean section. One limiting factor for its routine administration is the fact that there are also studies that did not prove the efficiency of ondansetron in the prevention of hypoten$\operatorname{sion}(41)$.

\section{Conclusion}

Hypotension occurring during spinal anaesthesia for caesarean section is the most common side effect of this type of anaesthesia, which requires specific prevention and treatment measures. A significant drop in blood pressure during caesarean section may jeopardise both the mother and the child, and it is important to implement steps to maintain optimal circulatory stability during surgery. Based on existing findings and considerable clinical experience, our approach to the prevention and treatment of hypotension is multimodal, combining the administration of crystalloids and/or colloids before and during anaesthesia, limiting the aortocaval compression of the pregnant uterus, administration of smaller doses of local anaesthetics combined with opioid analgesics, and administration of vasopressors. The least negative effect of phenylephrine on foetal acidosis makes it at this moment the vasopressor of choice. Rather than taking the reactive approach, it is recommended to start with prophylactic administration of phenylephrine by continuous infusion immediately after intrathecal administration of local anaesthetic.

\section{References}

1. The New York School of Regional Anesthesia (NYSORA) continuing medical education [Internet]. New York. [cited 2019 Feb 24] Spinal anesthesia; [about 111 KB]. Available from: https://www.nysora.com/techniques/neuraxial-and-perineuraxial-techniques/spinal-anesthesia/.

2. Corke BC, Datta S, Ostheimer GW, Weiss JB, Alper MH. Spinal anaesthesia for caesarean section. The influence of hypotension on neonatal outcome. Anaesthesia. 1982;37:658-62.

3. Kennedy RL, Friedman DL, Katcka DM, Selmants S, Smith RN. Hypotension during obstetrical anesthesia. Anesthesiology. 1959;20:153-5.

4. Klöhr S, Roth R, Hofmann T, Rossaint R, Heesen M. Definitions of hypotension after spinal anaesthesia for caesarean section: literature search and application to parturients. Acta Anaesthesiol Scand. 2010;54:909-921.

5. Burns SM, Cowan CM, Wilkes RG. Prevention and management of hypotension during spinal anaesthesia for elective Caesarean section: a survey of practice. Anaesthesia. 2001;56: 777-98.

6. Ngan Kee WD, Khaw KS, Ng FF. Comparison of phenylephrine infusion regimens for maintaining maternal blood pressure during spinal anaesthesia for Caesarean section. Br J Anaesth. 2004;92:469-74.

7. Kinsella SM, Carvalho B, Dyer RA, Fernando R, McDonnell $\mathrm{N}$ et al. International consensus statement on the management of hypotension with vasopressors during caesarean section under spinal anaesthesia. Anaesthesia. 2018;73(1):71-92.

8. Kestin IG. Spinal anaesthesia in obstetrics. Br J Anaesth. 1991;66:596-607.

9. Salinas FV, Sueda LA, Liu SS. Physiology of spinal anaesthesia and practical suggestions for successful spinal anaesthesia. Best Pract Res Clin Anaesthesiol. 2003;17(3):289-303.

10. McClure JH, Brown DT, Wildsmith JA. Effect of injected volume and speed of injection on the spread of spinal anaesthesia with isobaric amethocaine. Br J Anaesth. 1982;54:917-20.

11. Neal JM. Hypotension and bradycardia during spinal anesthesia: Significance, prevention, and treatment. Techniques in Regional Anesthesia and Pain Management. 2000;4(4):148-154.

12. Lewinsky RM, Riskin-Mashiah S. Autonomic imbalance in preeclampsia: evidence for increased sympathetic tone in response to the supine-pressor test. Obstet Gynecol. 1998;91: 935-39

13. Kashihara K. Roles of Arterial Baroreceptor Reflex During Bezold-Jarisch Reflex. Curr Cardiol Rev. 2009;5(4):263-267.

14. Borgeat A, Ekatodramis G, Schenker C A. Postoperative nausea and vomiting in regional anesthesia. Anesthesiology 2003; 98:530-547. 
15. Hirose N, Kondo Y, Maeda T, Suzuki T, Yoshino A. Relationship between regional cerebral blood volume and oxygenation and blood pressure during spinal anesthesia in women undergoing cesarean section. Journal of Anesthesia. 2016;30: 603-9.

16. Ratra CK, Badola RP, Bhargava KP. A study of factors concerned in emesis during spinal anaesthesia. British Journal of Anaesthesia. 1972;44:1208-11.

17. Hirose N, Kondo Y, Maeda T, Suzuki T, Yoshino A, Katayama Y. Oxygen supplementation is effective in attenuating maternal cerebral blood deoxygenation after spinal anesthesia for cesarean section. Advances in Experimental Medicine and Biology. 2016; 876: 471-7.

18. Cooperman LH. Effects of anaesthetics on the splanchnic circulation. British Journal of Anaesthesia. 1972;44:967-70.

19. Skillman CA, Plessinger MA, Woods JR, Clark KE. Effect of graded reductions in uteroplacental blood flow on the fetal lamb. American Journal of Physiology 1985;249:1098-105.

20. Corke BC, Datta S, Ostheimer GW, Weiss JB, Alper MH. Spinal anaesthesia for Caesarean section. The influence of hypotension on neonatal outcome. Anaesthesia.1982;37:658-62.

21. Okudaira S, Suzuki S. Influence of spinal hypotension on fetal oxidative status during elective cesarean section in uncomplicated pregnancies. Archives of Gynecology and Obstetrics. 2005; 271:292-5.

22. Maayan Metzger A, Schushan Eisen I, Todris L, Etchin A, Kuint J. Maternal hypotension during elective cesarean section and short-term neonatal outcome. Am J Obstet Gynecol. 2010; 202(1):93-94.

23. Hollmen AI, Jouppila R, Koivisto M, et al. Neurologic activity of infants following anesthesia for cesarean section. Anesthesiology 1978; 48: 350-6.

24. Ngan Kee WD, Khaw KS, Tan PE, Ng FF, Karmakar MK. Placental transfer and fetal metabolic effects of phenylephrine and ephedrine during spinal anesthesia for cesarean delivery. Anesthesiology. 2009;111:506-12.

25. Cooper DW, Carpenter M, Mowbray P, Desira WR, Ryall DM, Kokri MS. Fetal and maternal effects of phenylephrine and ephedrine during spinal anesthesia for cesarean delivery. Anesthesiology. 2002;97:1582-90.

26. Karinen J, Räsänen J, Alahuhta S, Jouppila R, Jouppila P. Effect of crystalloid and colloid preloading on uteroplacental and maternal haemodynamic state during spinal anaesthesia for caesarean section. Br J Anaesth. 1995;75: 531-5.

27. Park GE, Hauch MA, Curlin F, Datta S, Bader AM. The effects of varying volumes of crystalloid administration before cesarean delivery on maternal hemodynamics and colloid osmotic pressure. Anesth Analg. 1996;83:299-303.

28. Dyer RA, Farina Z, Joubert IA, et al: Crystalloid preload versus rapid crystalloid administration after induction of spinal anaesthesia (coload) for elective caesarean section. Anaesth Intensive Care. 2004;32(3):351-357.

29. Dahlgren G, Granath F, Pregner K, Rosblad PG, Wessel H, Irestedt L: Colloid vs. crystalloid preloading to prevent mater- nal hypotension during spinal anesthesia for elective cesarean section. Acta Anaesthesiol Scand. 2005;49(8):1200-1206.

30. Roofthooft E, Van de Velde M. Low-dose spinal anaesthesia for caesarean section to prevent spinal-induced hypotension. Curr Opin Anaesthesiol. 2008;21:259-62.

31. van Bogaert LJ. Prevention of post-spinal hypotension at elective cesarean section by wrapping of the lower limbs. Int J Gynaecol Obstet. 1998;61:233-8.

32. Sinclair CJ, Scott DB, Edstrom HH: Effect of the Trendelenberg position on spinal anaesthesia with hyperbaric bupivacaine. Br J Anaesth. 1982;54(5):497-500.

33. Ngan Kee WD, Khaw KS, Lee BB, Lau TK, Gin T. A dose response study of prophylactic intravenous ephedrine for the prevention of hypotension during spinal anesthesia for cesarean delivery. Anesth Analg. 2000;90:1390-5.

34. Habib AS. A Review of the Impact of Phenylephrine Administration on Maternal Hemodynamics and Maternal and Neonatal Outcomes in Women Undergoing Cesarean Delivery Under Spinal Anesthesia. Anesth Analg. 2012;114:377-90.

35. Thomas DG, Robson SC, Redfern N, Hughes D, Boys RJ. Randomized trial of bolus phenylephrine or ephedrine for maintenance of arterial pressure during spinal anaesthesia for caesarean section. Br J Anaesth. 1996;76:61-5.

36. Ngan Kee WD, Khaw KS, Ng FF: Prevention of hypotension during spinal anesthesia for cesarean delivery: An effective technique using combination phenylephrine infusion and crystalloid cohydration. Anesthesiology. 2005;103(4):744-750.

37. Ngan Kee WD, Lee SWY, Ng FF, Tan PE, Khaw KS. Randomized Double-blinded Comparison of Norepinephrine and Phenylephrine for Maintenance of Blood Pressure during Spinal Anesthesia for Cesarean Delivery. Anesthesiology. 2015; 122:736-45.

38. Wang X, Shen X, Liu S, Yang J, Xu S. The Efficacy and Safety of Norepinephrine and Its Feasibility as a Replacement for Phenylephrine to Manage Maternal Hypotension during Elective Cesarean Delivery under Spinal Anesthesia. BioMed Research International 2018. ID 1869189 , doi: 10.1155/2018/1869189

39. Sahoo T, SenDasgupta C, Goswami A, Hazra A. Reduction in spinal-induced hypotension with ondansetron in parturients undergoing caesarean section: a double-blind randomised, placebo-controlled study. International journal of obstetric anesthesia. 2012; 21(1): 24-8.

40. Tubog TD, Kane TD, Pugh MA. Effects of ondansetron on attenuating spinal anesthesia-induced hypotension and bradycardia in obstetric and nonobstetric subjects: a systematic review and meta-analysis. AANA J. 2017;85:113-22.

41. Oofuvong M, Kunapaisal T, Karnjanawanichkul O, Dilokrattanaphijit N, Leeratiwong J. Minimal Effective Weight-based Dosing of Ondansetron to Reduce Hypotension in Cesarean Section Under Spinal Anesthesia. BMC Anesthesiol. 2018;18 (105):2-9. 


\section{Sažetak \\ SPINALNOM ANESTEZIJOM INDUCIRANA HIPOTENZIJA U OPSTETRICIJI: PREVENCIJA I TERAPIJA}

\section{I. Šklebar, T. Bujas i D. Habek}

Regionalna centroaksijalna anestezija, prvenstveno spinalni blok, danas je metoda izbora za anesteziju pri elektivnom carskom rezu jer nosi manje rizike za majku i fetus u odnosu na opću anesteziju. Najčešća komplikacija spinalnog bloka je hipotenzija koja se javlja u jedne do tri četvrtine slučajeva uslijed simpatikolize. Simpatikoliza inducirana spinalnim blokom dovodi do vazodilatacije te na taj način uzrokuje hipotenziju u majke što može kompromitirati uterini protok krvi i fetalnu cirkulaciju uzrokujući fetalnu hipoksiju, bradikardiju i acidozu.Potraga za najefikasnijom terapijskom strategijom kako bi se postigla hemodinamska stabilnost tijekom spinalne anestezije za carski rez i dalje je jedan od glavnih izazova u opstetričkoj anesteziji. U kliničkoj praksi primjenjuje se više mjera prevencije i terapije hipotenzije uzrokovane spinalnim blokom kao što je prehidracija i kohidracija infuzijom kristaloida i/ili koloida, kompresija donjih ekstremiteta elastičnim zavojima ili čarapama, optimiziranje doze lokalnog anestetika i visine spinalnog bloka, pozicioniranje s nagibom na lijevi bok te primjena inotropa i vazopresora. Umjesto primjene vazopresora nakon što nastupi pad tlaka, noviji algoritmi preporučuju profilaktičku primjenu vazopresora u infuziji pri čemu izbor pada na fenilefrin kao najčešće korišten vazokonstriktor jer se pokazalo da najmanje utječe na pojavu fetalne acidoze te mučnine i povraćanja u majke u odnosu na druge vazokonstriktore.

Ključne riječi: spinalna anestezija, carski rez, hipotenzija, kristaloidi, koloidi, vazopresori, efedrin, fenilefrin, noradrenalin, ondansetron 